\title{
PERBEDAAN SIKLUS MENSTRUASI ANTARA AKSEPTOR KB SUNTIK 1 BULAN DAN AKSEPTOR KB SUNTIK 3 BULAN DI BPM NY. "S" DESA KLUWIH KECAMATAN TULAKAN KABUPATEN PACITAN
}

\author{
Murniati $^{1)}$, Astrilinda Cahya Thoni Putri ${ }^{2)}$ \\ Akbid Harapan Mulya Ponorogo ${ }^{122}$ \\ murniati@gmail.com ${ }^{1)}$ cahyaputri@gmail.com ${ }^{2)}$
}

\begin{abstract}
Menstruation is regular bleeding from the uterus as a sign that the uterus has fulfilled its function. Based on preliminary data through interviews on long term acceptor KB 3 month injection and long term acceptor KB injection 1 month on 25 November 2016 which amounted to 20 people in BPM Ny "S" of Kluwih village Tulakan sub district of Pacitan. Of the 10 people who injected 1 month injection is not complaining about the menstrual cycle. While from 10 injectors of 3 month injection, regular menstrual cycles were 6 respondents (60\%) and irregular menstrual cycle were 4 respondents (40\%). This study aims to determine the difference of menstrual cycle between 1 month injection acceptor and 3 month injection acceptor in BPM Ny. S Village Kluwih Tulakan District Pacitan.

This type of research is comparative analytic. The research design in this research is analytical case control (retrospective). The variable in this research is menstrual cycle between 1 month injection acceptor and 3 month injection. Measuring tools used interview. Population of 80 injection contraceptive injectors (40 1 month injections of contraceptive injectors, 403 month injecting of KB acceptor) and 60 samples of $K B$ acceptor using accidental sampling technique in February 2017.Method of data analysis using T test with significance determined by value $\rho<0.05$.

The results showed that the frequency of menstrual cycle of 1 month injections of contraceptive injectors showed that from 30 respondents, 26 respondents (86,7\%), menstruation cycle 28-35 days (regular), and 3 month period of menstruation of 3 month injecting contraception showed that from 30 respondents obtained more than half or 21 respondents (70\%) menstrual cycle > 35 days (irregular). Based on the result of paired $T$ Test test, the signification level is 0,000 <0,05 so that HO is accepted, meaning that there is difference of menstrual cycle of 1 month injection acceptor and 3 month injection contraceptive injection.

It is suggested to the officer to increase the extension activity to $K B$ injectors to increase knowledge and insight about side effects of injecting $K B$.
\end{abstract}

\section{Keywords: Menstrual Cycle, Injection Contraceptive Acceptor, 1 Month Injection And 3 Month Injection}

\section{PENDAHULUAN}

Menstruasi merupakan perdarahan teratur dari uterus sebagai tanda bahwa alat kandungan telah menunaikan faalnya. Pada wanita biasanya pertama kali mengalami menstruasi (menarche) pada umur $12-16$ tahun. Siklus menstruasi normal terjadi setiap 22-35 hari,dengan lamanya menstruasi selama 2 -7 hari. (Kusmiran, 2012).
Untuk dapat mengangkat derajat kehidupan bangsa telah dilaksanakan secara bersamaan pembangunan ekonomi dan keluarga berencana. Program Nasional KB diarahkan pada dua bentuk sasaran : (1) sasaran langsung yaitu Pasangan Usia Subur (PUS) 15 - 49 tahun, dengan jalan mereka secara bertahap menjadi peserta $\mathrm{KB}$ yang aktif lestari, sehingga memberi efek langsung menurunkan fertilitas. (2) sasaran tidak langsung yaitu organisasi-organisasi, 


\section{Jurnal Delima Harapan 2019}

lembaga-lembaga kemasyarakatan, instansiinstansi pemerintah maupun swasta, tokohtokoh masyarakat (alim ulama, wanita dan pemuda),yang diharapkan dapat memberikan dukungannya dalam pelembagaan NKKBS (Hartanto, 2004).

Sejumlah perempuan mengeluhkan pemakaian metode kontrasepsi menyebabkan masalah menstruasi. Masalah tersebut dapat berupa tidak mengalami menstruasi sama sekali sampai menstruasi berat dan berkepanjangan. Memang banyak keluhan ibu-ibu terkait dengan penggunaan metode kontrasepsi, termasuk gangguan tidak teraturnya menstruasi. Namun itu sifatnya hormonal dan tidak semua orang mengalami keluhan yang sama. Kemungkinan yang terjadi karena hormonnya tidak sesuai dan tidak seimbang (Fitriliada, 2012 dalam Arini, 2003).

Menurut survei demografi dan Kesehatan Indonesia tahun 2007 diantara cara KB modern suntikan merupakan alat kontrasepsi yang paling banyak dipakai para wanita yang pernah kawin maupun wanita berstatus kawin (masing- masing 30,00\% dan 32,00\%) (Hartanto, 2004).

Jumlah Pasangan Usia Subur (PUS) tahun 2014 ada 212.898 pasangan.Peserta $\mathrm{KB}$ aktif ada 140.651 pasangan $(66,1 \%)$. Sedangkan untuk jumlah peserta KB baru Kabupaten Pacitan tahun 2014 ada 7.219 pasangan $(3,4 \%)$. Presentasi pemakaian kontrasepsi peserta KB aktif tahun 2014 terdiri dari : peserta pil 9,39\%, IUD 31,58\%, MOP 0,21\%, MOW 3,81\%, Implant 6,33\%, kondom $1,21 \%$ dan suntik 47,47\%. Dan pada presentasi pemakaian kontrasepsi peserta KB baru tahun 2014 terdiri dari : peserta pil $8,03 \%$, IUD $13,16 \%$, MOP $1,01 \%$, MOW 1,99\%, Implant 25,09\%, kondom $0,91 \%$ dan suntik 49,80\%. Dari data tersebut dapat diketahui bahwa bagian terbesar peserta KB baru dan aktif mempergunakan alat kontrasepsi hormonal, yaitu suntikan (yang paling banyak), pil, IUD, dan implan (Dinkes Pacitan, 2014).

Data dari Puskesmas Tulakan, jumlah peserta $\mathrm{kb}$ aktif yang menggunakan kontrasepsi suntik ada 8,449 (41\%) dan peserta $\mathrm{KB}$ baru dengan alat kontrasepsi suntik ada 350 (56\%). Sedangkan akseptor KB suntik di desa Kluwih berjumlah 80 orang.

Berdasarkan studi pendahuluan pada akseptor lamaKB suntik 3 bulan dan akseptor lama KB suntik 1 bulan tanggal 25 November 2016 yang berjumlah 20 orang di BPM Ny."S" desa Kluwih kecamatan Tulakan kabupaten Pacitan. Terdapat 10 orang akseptor $\mathrm{KB}$ suntik 1 bulan dan 10 orang akseptor KB suntik 3 bulan. Dari 10 orang akseptor $\mathrm{KB}$ suntik 1 bulan dengan sikus mentruasi teratur sebanyak 5 responden $(50 \%)$ dan dengan siklus menstruasi tidak teratur sebanyak 5 responden $(50 \%)$. Dari 10 orang akseptor KB suntik 1 bulan tersebut tidak mengeluh terhadap siklus haid. Sedangkan dari 10 orang akseptor $\mathrm{KB}$ suntik 3 bulan dengan sikus mentruasi teratur sebanyak 6 responden $(60 \%)$ dan dengan siklus menstruasi tidak teratur sebanyak 4 responden $(40 \%)$. Dari 10 orang akseptor KB suntik 3 bulan tersebut mengeluh terhadap spoting 5 orang,perubahan berat badan 3 orang dan 2 orang tidak mengeluh.

Ada beberapa masalah yang sering ditemukan pada akseptor kontrasepsi suntik. Efek samping terjadi pada akseptor kontrasepsi suntik adalah gangguan haid (amenore, perdarahan ireguler, perdarahan bercak) berat badan bertambah dan sakit kepala. Pada umumnya penambahan berat badan tidak terlalu besar, bervariasi antara kurang dari $1 \mathrm{~kg}$ sampai $5 \mathrm{~kg}$ dalam tahun pertama. Sedangkan insidens yang tinggi dari amenore diduga berhubungan dengan atrofi endometrium. (Hartanto, 2004).

Dampak yang sering ditemukan pada akseptor kontrasepsi suntik ini salah satunya adalah perubahan berat badan, gangguan haid, depresi, keputihan, jerawat dan sebagainya. Gangguan pola haid yang terjadi tergantung pada lama pemakaian. Gangguan pola haid yang sering terjadi pada akseptor seperti terjadi perdarahan bercak/flek, perdarahan irreguler, amenorea dan perubahan dalam frekuensi, lama dan jumlah darah yang hilang. Clycloprovera dapat menimbulkan perdarahan teratur tiap bulan, mengurangi perdarahan bercak atau 


\section{Jurnal Delima Harapan 2019}

perdarahan irreguler lainnya. Efek samping lebih cepat hilang setelah suntikan dihentikan (Hartanto, 2010).

Dampak yang terjadi di BPM banyak ibu akseptor KB suntik 3 bulan mengeluh siklus menstruasi tidak teratur setiap bulan, sebagian ibu juga mengeluh perdarahan bercak/flek,amenore, dan perubahan pada berat badan. Sedangkan pada akseptor KB suntik 1 bulan tidak mengeluh pada siklus haid.

Oleh karena itu, perlu dilakukan upaya untuk mencegah terjadinya efek samping yang berlebihan pada akseptor kontrasepsi suntik. Salah satu cara mengatasi masalah tersebut adalah dengan memberikan KIE berupa keuntungan, kerugian, cara kerja, serta efek samping kontrasepsi suntik. Perlu juga pengaturan pola makan, jenis makanan yang harus dikonsumsi dan harus dihindari. Selain itu, olahraga dan aktifitas juga harus ditingkatkan.

\section{METODE PENELITIAN}

Jenis penelitian ini adalah analitik komparatif dengan desain penelitian case control (retrospective). Penelitian ini dilaksanakan di BPM Ny. "S" Desa Kluwih Kecamatan Tulakan Kabupaten Pacitan pada bulan Februari 2017.

Populasi yang digunakan adalah semua akseptor lama KB suntik 1 bulan dan KB suntik 3 bulan, jumlah yang berkunjung dari bulan November - Desember 2016 di BPM Ny "S" Desa Kluwih Kecamatan Tulakan Kabupaten Pacitan 80 orang. Sampel dalam penelitian ini adalah semua akseptor ulang KB suntik 1 bulan dan akseptor KB suntik 3 bulan yang berkunjung bulan Februari 2017 dengan jumlah 60 orang. SAmpel diambil menggunakan teknik Accidental Sampling.

Penelitian ini memiliki variabel terikat yaitu siklus menstruasi aksepor KB suntik 1 bulan dan $\mathrm{KB}$ suntik 3 bulan. Instrumen yang digunakan adalah rekam medik untuk mengetahui keteraturan siklus menstruasi dan kontrasepsi yang digunakan oleh akseptor.

Analisa data untuk menguji hipotesis komparatif rata-rata satu sampel bila datanya interval menggunakan uji statistic $t$ test dengan bantuan komputer SPSS versi 16 for Windows pada taraf signifikan 0,05. Ha diterima bila $\mathrm{p}<0,05$ dan ditolak bila $\mathrm{p}$ $>0,05$.

\section{HASIL}

1) Siklus Menstruasi Akseptor KB Suntik 1 Bulan.

Tabel 1. Distribusi Frekuensi Siklus Menstruasi Akseptor KB Suntik 1 Bulan di BPM Ny. S Desa Kluwih Kecamatan Tulakan Kabupaten Pacitan Pada Bulan Februari 2017

\begin{tabular}{|c|l|l|c|c|}
\hline No. & $\begin{array}{l}\text { Siklus } \\
\text { Menstruasi }\end{array}$ & Kategori & Frekuensi & $\begin{array}{c}\text { Prosentase } \\
(\%)\end{array}$ \\
\hline 1 & $<28$ hari & $\begin{array}{l}\text { Tidak } \\
\text { teratur }\end{array}$ & 0 & 0 \\
\hline 2 & $28-35$ hari & Teratur & 26 & 86,7 \\
\hline 3 & $>35$ hari & $\begin{array}{l}\text { Tidak } \\
\text { teratur }\end{array}$ & 4 & 13,3 \\
\hline \multicolumn{2}{|c|}{ Jumlah } & & 30 & 100 \\
\hline
\end{tabular}

Berdasarkan tabel 1 dari 30 responden yang dtelitii didapatkan hampir seluruhnya 26 responden $(86,7 \%)$ siklus menstruasi 28-35 hari (teratur) sedangkan sebagian kecil 4 responden $(13,3 \%)$ siklus menstruasi $>35$ hari (tidak teratur).

2) Siklus Menstruasi Akseptor KB Suntik 3

Bulan

Tabel 2. Distribusi Frekuensi Siklus Menstruasi Akseptor KB Suntik 3 Bulan di BPM Ny. S Desa Kluwih Kecamatan Tulakan Kabupaten Pacitan Pada Bulan Februari 2017.

\begin{tabular}{|c|c|c|c|c|}
\hline No. & $\begin{array}{l}\text { Siklus } \\
\text { Menstruasi }\end{array}$ & Kategori & Frekuensi & $\begin{array}{c}\text { Prosentase } \\
(\%)\end{array}$ \\
\hline 1 & $<28$ hari & $\begin{array}{l}\text { Tidak } \\
\text { teratur }\end{array}$ & 0 & 0 \\
\hline 2 & 28-35 hari & Teratur & 9 & 30 \\
\hline 3 & $>35$ hari & $\begin{array}{l}\text { Tidak } \\
\text { teratur }\end{array}$ & 21 & 70 \\
\hline & Jumlah & & 30 & 100 \\
\hline
\end{tabular}

responden yang dtelitii didapatkan lebih dari setengahnya 21 responden $(70 \%)$ siklus menstruasi $>35$ hari (tidak teratur) sedangkan sebagian kecil 9 responden $(30 \%)$ siklus menstruasi 28-35 hari (teratur).

3) Tabulasi Silang Perbedaan Siklus Menstruasi Akseptor KB Suntik. 


\section{Jurnal Delima Harapan 2019}

Tabel 3. Tabulasi Silang Perbedaan Siklus Menstruasi Akseptor KB Suntik 1 Bulan Dan KB Suntik 3 Bulan di BPM Ny. S Desa Kluwih Tulakan Pacitan Februari 2017.

\begin{tabular}{|l|r|r|r|}
\hline & \multicolumn{2}{|l|}{ Siklus Menstruasi } & \multirow{2}{*}{ Total } \\
\cline { 2 - 4 } & $\begin{array}{l}\text { Tidak } \\
\text { Teratur }\end{array}$ & Teratur & \\
\hline Suntik 1 bulan & 4 & 26 & 30 \\
& $6.7 \%$ & 43,3 & $50 \%$ \\
\hline Suntik 3 bulan & 21 & 9 & 30 \\
& $35 \%$ & $15 \%$ & $50 \%$ \\
\hline Total & 25 & 35 & 60 \\
& $41,7 \%$ & $58,3 \%$ & $100 \%$ \\
\hline
\end{tabular}

Dari tabel diatas, dari 60 responden yang diteliti didapatkan 30 responden akseptor suntik 1 bulan,4 orang $(6,7 \%)$ siklus menstruasi tidak teratur dan 26 orang $(43,3 \%)$ siklus menstruasi teratur. Sedangkan untuk akseptor suntik 3 bulan dari 30 responden yang diteliti, 21 orang $(35,0 \%)$ siklus menstruasi tidak teratur dan 9 orang $(15,0 \%)$ siklus menstruasi teratur.

4) Perbedaan Siklus Menstruasi

Tabel 4. Perbedaan Siklus Menstruasi Akseptor KB Suntik 1 Bulan Dan Akseptor KB Suntik 3 Bulan di BPM Ny. S Desa Kluwih Kecamatan Tulakan Kabupaten Pacitan Pada Bulan Februari 2017

\begin{tabular}{|c|c|c|c|c|c|c|c|c|}
\hline & \multicolumn{8}{|c|}{ Paired Differences } \\
\hline & \multirow{2}{*}{ Mean } & \multirow{2}{*}{$\begin{array}{c}\text { Std. } \\
\text { Deviation }\end{array}$} & \multirow{2}{*}{$\frac{\text { Std.eror }}{\text { Mean }}$} & \multicolumn{2}{|c|}{$95 \%$} & \multirow{2}{*}{$t$} & \multirow{2}{*}{$\mathrm{df}$} & \multirow{2}{*}{$\begin{array}{l}\text { Sig 2- } \\
\text { tailed }\end{array}$} \\
\hline & & & & Lower & Upper & & & \\
\hline $\begin{array}{l}\text { Pair } 1 \text { Siklus } \\
\text { Menstruasi- } \\
\text { Akseptor Kb } \\
\text { Suntik } 1 \text { bulan } \\
\text { dan } 3 \text { bulan }\end{array}$ & .917 & 889 & 115 & 687 & 1.146 & 7.991 & 59 & .000 \\
\hline
\end{tabular}

Dari hasil perhitungan SPSS for windows 16 didapatkan hasil nilai $\mathrm{p}$ value 0,000 maka dapat disimpulkan bahwa tidak ada perbedaan keteraturan siklus menstruasi ibu akseptor KB suntik 1 bulan dan akseptor KB suntik 3 bulan. Sig. (2-tailed) : Nilai probabilitas / $\mathrm{p}$ value uji $\mathrm{T}$ Paired: Hasil $=$ 0,000 . Artinya ada perbedaan siklus menstruasi akseptor KB suntik 1 bulan dan akseptor KB suntik 3 bulan. Sebab : Nilai $p$ value $<0,05$. 


\section{Jurnal Delima Harapan 2019}

\section{PEMBAHASAN}

1. Siklus Menstruasi Akseptor KB Suntik 1 Bulan

Setelah dilakukan analisa dan penyimpulan data didapatkan hasil sebagai berikut : Berdasarkan tabel 5.5 dari 30 responden yang diteliti didapatkan hampir seluruhnya 26 responden $(86,7 \%)$ siklus menstruasi 28-35 hari (teratur) sedangkan sebagian kecil 4 responden $(13,3 \%)$ siklus menstruasi $>35$ hari (tidak teratur).

Menstruasi adalah proses pengeluaran darah dari uterus yang disertai serpihan selaput dinding uterus pada wanita dewasa yang terjadi secara periodik. Menstruasi dikategorikan teratur apabila perdarahan menstruasi yang normal berlangsung kurang lebih 4-7 hari. Jumlah darah yang keluar sekitar $2-8$ sendok makan. Sementara itu panjang siklus menstruasi rata-rata adalah $28-35$ hari (kategori teratur)(Rahayu dkk,2011:109).

Faktor yang mempengaruhi siklus menstruasi faktor hormon : Hormon hormon yang mempengaruhi terjadinya haid pada seorang wanita yaitu : (1) Follicle Stimulating Hormone (FSH) yang dikeluarkan oleh hipofisis (2) Estrogen yang dihasilkan oleh ovarium (3) Luteinizing Hormone (LH) yang dihasilkan oleh hipofisis (4) Progesteron yang dihasilkan oleh ovarium.(Eny Kusmiran, 2012).

Berdasarkan hasil penelitian tersebut, peneliti berpendapat bahwa siklus menstruasi dikatakan teratur bias terjadi karena hormone dalam siklus menstruasi ibu stabil dan kandungan obat dalam KB suntik 1 bulan sesuai dengan kondisi ibu sehingga menyebabkan siklus menstruasi teratur.

2. Siklus Menstruasi Akseptor KB Suntik 3 Bulan

Dari penelitian didapatkan lebih dari setengahnya 21 responden $(70 \%)$ siklus menstruasi > 35 hari (tidak teratur) sedangkan sebagian kecil 9 responden $(30 \%)$ siklus menstruasi 28-35 hari (teratur).
Menstruasi dikategorikan teratur apabila pendarahan menstruasi yang normal berlangsung kurang lebih 4-7 hari. Jumlah darah yang keluar sekitar 2-8 sendok makan. Sementara itu, panjang satu siklus menstruasi rata-rata adalah 28 - 35 hari.Menstruasi dikategorikan tidak teratur apabila panjang siklus menstruasi terpisah lebih dari 35 hari atau kurang dari 28 hari, terhitung mulai dari menstruasi hari pertama hingga terjadi menstruasi berikutnya, tidak mengalami menstruasi selama 3 bulan berturut-turut. (Rahayu dkk, 2011).

Faktor yang mempengaruhi siklus menstruasi faktor hormon : Hormon hormon yang mempengaruhi terjadinya haid pada seorang wanita yaitu : (1) Follicle Stimulating Hormone (FSH) yang dikeluarkan oleh hipofisis (2) Estrogen yang dihasilkan oleh ovarium (3) Luteinizing Hormone (LH) yang dihasilkan oleh hipofisis (4) Progesteron yang dihasilkan oleh ovarium. (Eny Kusmiran,2012:106-107).

Berdasarkan hasil penelitian tersebut, peneliti berpendapat bahwa siklus menstruasi dikatakan tidak teratur bias terjadi karena pengaruh hormon dan apabila lendir serviks tidak mengental maka kemungkinan kehamilan akan tetap terjadi. Maka dari itu konseling saat ibu berkunjung sangat diperlukan agar ibu tidak takut akan keadaan ini.

3. Perbedaan Siklus Menstruasi Akseptor KB Suntik 1 Bulan Dan Akseptor KB Suntik 3 Bulan

Dari tabel 5.7, menunjukkan bahw asebanyak 60 responden yang diteliti didapatkan 30 responden akseptor suntik 1 bulan, 4 orang $(6,7 \%)$ siklus menstruasi tidak teratur dan 26 orang $(43,3 \%)$ siklus menstruasi teratur. Sedangkan untuk akseptor suntik 3 bulan dari 30 responden yang diteliti, 21 orang $(35,0 \%)$ siklus menstruasi tidak teratur dan 9 orang $(15,0 \%)$ siklus menstruasi teratur.

Dari hasil perhitungan SPSS for windows 16 didapatkan hasil nilai $\mathrm{p}$ value 0,000 maka dapat disimpulkan bahwa tidak ada perbedaan keteraturan siklus 


\section{Jurnal Delima Harapan 2019}

menstruasi ibu akseptor KB suntik 1 bulan dan akseptor KB suntik 3 bulan.Dari penelitian didapatkan Sig. (2tailed) : Nilai probabilitas / $\mathrm{p}$ value uji $\mathrm{T}$ Paired: Hasil $=0,000$. Artinya : ada perbedaan siklus menstruasi akseptor KB suntik 1 bulan dan akseptor KB suntik 3 bulan. Sebab : Nilai p value < 0,05 (95\% kepercayaan).

Penyebab tidak teraturnya siklus menstruasi dalam penggunaan $\mathrm{KB}$ suntik salah satunya adalah akibat mengentalnya lendir servik sehingga tidak terjadi ovulasi, (Saifuddin, 2003: MK-40). Selain itu menghalangi pengeluaran FSH dan LH sehingga tidak terjadi pelepasan ovum, perubahan pada endometrium. (Manuaba dkk, 2010).

Hal ini sesuai dengan penelitian Lia Christina Ragil Saputri (2014) dengan judul " Perbedaan Berat Badan Dan Siklus Menstruasi Ibu Sebelum Dan Sesudah Menggunakan KB Suntik 3 Bulan Di BPM Ny "M" Desa Ploso Jenar Kecamatan Kauman Kabupaten Ponorogo 3 Bulan Di BPM Ny "M" Desa Ploso Jenar Kecamatan Kauman Kabupaten Ponorogo". Hasil menunjukan bahwa Sig. (2-tailed) : Nilai probabilitas / p value uji $\mathrm{T}$ Paired: Hasil $=0,000$. Artinya : ada perbedaan siklus menstruasi ibu antara sebelum dan sesudah menggunakan KB suntik 3 bulan. Sebab : Nilai $\mathrm{p}$ value < 0,05 .

Dari hasil perhitungan SPSS for windows 16 didapatkan hasil nilai $\mathrm{p}$ value 0,000 maka dapat disimpulkan bahwa ada perbedaan berat badan dan keteraturan siklus menstruasi ibu sebelum dan sesudah menggunakan KB suntik 3 bulan.

\section{KESIMPULAN SARAN}

1. Kesimpulan

a. Siklus menstruasi akseptor KB suntik 1 bulan di BPM Ny. S DesaKluwih Kecamatan Tulakan Kabupaten Pacitan didapatkan hampir seluruhnya 26 responden (86,7\%), siklus menstruasi 28-35 hari (kategori teratur).

b. Siklus menstruasi akseptor KB suntik 3 bulandi BPM Ny. S DesaKluwih
Kecamatan Tulakan Kabupaten Pacitandidapatkan lebih dari setengahnya 21 responden (70\%) siklus menstruasi > 35 hari (tidak teratur).

c. Ada perbedaan siklus mentruasi akseptor KB suntik 1 bulan dan akseptorKB suntik 3 bulan didapatkan hasil Sig. (2-tailed) : Nilai probabilitas / $\mathrm{p}$ value uji $\mathrm{T}$ Paired: Hasil $=0,000$. Artinya : ada perbedaan siklus menstruasi akseptor $\mathrm{KB}$ suntik 1 bulan dan akseptor KB suntik 3 bulan. Sebab : Nilai p value $<0,05$.

2. Saran

1) Bagi Ibu

Diharapkan ibu yang menggunakan $\mathrm{KB}$ suntik mengetahui efek samping apa saja yang mungkin terjadi.

2) Bagi Bidan

Diharapkan bidan lebih meningkatkan penyuluhan dan informasi pada akseptor $\mathrm{KB}$, terutama pada akseptor $\mathrm{KB}$ suntik 1 bulan dan akseptor KB suntik 3 bulan. Sehingga mereka mengerti tentang efek samping dari KB suntik yang sedang atau akan digunakan. Serta meningkatkan mutu pelayanan dalam masyarakat.

3) Bagi Institusi Pendidikan

Diharapkan hasil penelitian ini dapat dipergunakan sebagai bahan referensi tentang Perbedaan Siklus Menstruasi Antara Akseptor KB Suntik 1 Bulan Dan Akseptor KB Suntik 3 Bulan Di BPM Ny. S Desa Kluwih Kecamatan Tulakan Kabupaten Pacitan.

4) Bagi Peneliti Lain

Diharapkan mampu meneliti efek samping apa saja yang mempengaruhi ibu akseptor KB suntik baik itu suntik 1 bulan maupun suntik 3 bulan.

DAFTAR PUSTAKA

Arikunto. 2006. Metode Penelitian Kualitatif Dan Kuantitatif. Jakarta: Rineka Cipta 2010. Prosedur Penelitian Suatu Pendekatan Praktik. Jakarta: Rineka Cipta 


\section{Jurnal Delima Harapan 2019}

Dinkes Pacitan. 2014.Profil Kesehatan

Pacitan, (online PDF), (http://www.depkes.go.id)

diakses 05 Desember 2016

Dyah, Noviyawati Setya Dan Sujiyatini.

2011. Panduan Lengkap

Pelayanan KB Terkini.

Jogjakarta: Nuha Medika

Handayani, Sri. 2010. Buku Ajaran Pelayanan Keluarga Berencana. Yogyakarta: Rihana

Hartanto, Hanafi. 2004. Keluarga Berencana Dan Kontrasepsi. Jakarta: Pustaka Sinar Harapan

Kusmiran, Eny. 2012. Kesehatan Reproduksi Remaja Dan Wanita. Jakarta: Salemba Medika

Meilani, Niken dkk. 2010. Pelayanan Keluarga Berencana.

Yogyakarta: Citramaya

Manuaba, IBG dkk. 2010. Ilmu

Kebidanan, Penyakit Kandungan, Dan KB. Jakarta: EGC

Mulyani, Nina, Siti, \& Rinawati, Mega. 2013. Keluarga Berencana Dan Alat Kontraspsi. Yogyakarta: Nuha Medika

Notoatmojo, Soekidjo. 2005. Metode Penelitian Kesehatan. Jakarta: Rineka Cipta

․ 2010. Metode Penelitian Kesehatan. Jakarta: Rineka Cipta . 2012. Metodologi Penelitian Kesehatan. Jakarta: Rineka Cipta

Nursalam. 2001. Konsep Dan Penerapan Metodologi Penerapan Ilmu Keperawatan. Jakarta: Salemba Medika - 2013. Konsep Dan Penenrapan Metodologi Penenlitian Ilmu Keperawatan. Jakarta: Salemba Medika

Rahayu, Lisdyawati Dan Verawati, Sri Nor. 2012. Merawat Dan Menjaga Kesehatan Seksual Wanita. Bandung: Grafindo Media Pratama

Saifuddin, Abdul Bari. 2003. Buku Panduan Praktis Pelayanan Kontrasepsi. Jakarta: Tridasa Printer

Varney, Hellen. 2007. Buku Ajar Asuhan Kebidanan. Jakarta: EGC 